Microbes and Health

ISSN: 2226-0153 (Print) 2305-3542 (Online)

http://journal.bsvmph.org/

Microbes and Health, December 2012, 1(2): 81-85

DOI: $10.3329 /$ mh.v1i2.14096

\title{
Qualitative and Bacteriological Assessment of Commercially Available Bottled Water in the City of Mymensingh, Bangladesh
}

\author{
Shabnam Sharmin, S. M. Lutful Kabir ${ }^{*}$ and M. Mufizur Rahman \\ Department of Microbiology and Hygiene, Bangladesh Agricultural University, Mymensingh-2202, Bangladesh \\ *Corresponding author's e-mail: lkabir79@gmail.com
}

[Received: 05 December 2012, Revised: 18 December 2012, Accepted: 24 December 2012]

\begin{abstract}
A B S T R A C T
Bottled water has become one of the most popular drinks in Bangladesh. Now a days it is easily available in the market. The objectives of this study were to assess the overall quality (qualitative and bacteriological) of bottled water samples in the city of Mymensingh, Bangladesh. For achieving the objectives, standard questionnaire, methods of heterotrophic plate count (HPC) and total coliform count (TCC) were applied. Qualitative assessment of bottled water indicated that a good number of people preferred bottled water to tap water. The criterion in order to qualify for a 'good bottled water' was the taste $(43.3 \%)$. The bottled water quality was satisfactory in $40 \%$ of the responders in this study on the basis of peoples' satisfactions, perceptions and expenditures on bottled water quality. On the other hand, the percentage of dumping of bottled water after consumption refuse was $33.3 \%$. Monthly expenditure on bottled water was less than 300 taka in $80 \%$ of the responders. The geometric mean of HPC of different brands of bottled water ranged from $2.9 \times 10^{3} \mathrm{cfu} / 100 \mathrm{ml}$ to $6.2 \times 10^{3}$ $\mathrm{cfu} / 100 \mathrm{ml}$. In addition, the geometric mean of TCC of different brands of bottled water ranged from $9 \mathrm{cfu} / 100 \mathrm{ml}$ to $43 \mathrm{cfu} / 100 \mathrm{ml}$. The results indicate that most of the bottled water studied were out of their safety guidelines. Recommendations for better treatment systems for bottled drinking water to address the issue appears to be essential.
\end{abstract}

Keywords: Quality, Bacteriological Assessment, Bottle Water

(C) 2012 Microbes and Health. All rights reserved

\section{Introduction}

The World Health Organization has estimated that up to $80 \%$ of all sicknesses and diseases in the world are caused by inadequate sanitation, polluted water or unavailability of water. It was estimated that nearly 1.5 billion people lack safe drinking water and that at least 5 million deaths per year can be attributed to water- borne diseases. Health effects associated with water supplies in developing countries are based on four bacterial indicators of tropical drinking-water quality (faecal coliforms, Escherichia coli, Enterococci and faecal Streptococci) and their relationship to the prevalence of diarrhoeal disease in Cebu, Philippines (Moe et al. 1991). The contaminated water or inadequate supply of safe drinking water causes various gastrointestinal diseases like diarrhoea, dysentery and other water-borne diseases like cholera and typhoid. It is now evident that most of the enteric diseases of human and animals are transmitted through contaminated food and water (Johnson et al. 2003). The transmission of waterborne diseases is still a matter of major concern, despite worldwide efforts and modern technologies are being utilized for the production of safe drinking water (Venter, 2000). This problem is not only confined to the developing world where water treatment may not exist or is inadequate, but also in some developed countries. There may also be contamination during storage, lack of regulations, limited understanding and awareness among the population (American Academy of Microbiology, 1996).

To cite this article: Sharmin S, SML Kabir and MM Rahman, 2012. Qualitative and bacteriological assessment of commercially available bottled water in the city of Mymensingh, Bangladesh. Microbes Health, 1(2): 81-85.
Effective marketing and a general skepticism on the quality of tap water resulted increased consumptions of bottled/dispenser waters (Liguori et al., 2010). As neither treatment nor bottling or materials shall otherwise change the natural composition of the water, large bacterial populations usually develop from small initial populations shortly after production (Loy et al., 2005). Although the concept of safe water is much discussed and is under consideration to address in Bangladesh, there is no or little science-based information available. Therefore, the present study was conducted to determine the qualitative and bacteriological assessments of bottled water available in the open market in Mymensingh city, Bangladesh.

\section{Materials and Methods}

Collection of bottled water samples

A total of 30 bottled water samples from 5 different domestic brands ( 5 from each brand) were collected randomly from retail stores in Mymensingh, Bangladesh during October to November, 2012. After collecting water samples in a conical flask, the mouth and neck of flask was covered with aluminum foil and taken to the bacteriology laboratory of the Department of Microbiology and Hygiene, Bangladesh Agricultural University (BAU), Mymensingh, Bangladesh for detail investigation.

Questionnaire for qualitative assessment

To acquire a public perception regarding bottled water in the Mymensingh city of Bangladesh, a questionnaire survey was designed (questionnaire not shown). 


\section{Heterotrophic Plate Count (HPC)}

For the determination of heterotrophic plate count, 100 micro liter of a tenfold serial dilution of bottled water and 100 micro liters of a tenfold serial dilution of tap water from original samples were transferred and spread onto a nutrient agar media using micro pipette for each dilution. The diluted samples were spread as quickly as possible on the surface of plate with a sterile glass spreader. One sterile glass spreader was used for each plate .The plates were then incubated at $37^{\circ} \mathrm{C}$ for $24-48$ hours. Following incubation, plates exhibiting 30-300 colonies were counted. The heterotrophic plate count was calculated according to ISO (1995). The result of total bacterial count was expressed as the number of organism or colony forming units per milliliter $(\mathrm{CFU} / \mathrm{ml})$ of water samples.

\section{Total Coliform Count (TCC)}

For the determination of total Coliform count, 100 micro liter of serial tenfold dilution of bottled water and 100 micro liters of serial ten fold dilution of tap water from original samples were transferred and spread on MacConkey agar media using micro pipette for each dilution. The diluted samples were spread as quickly as possible on the surface of plate with a sterile glass spreader. One sterile glass spreader was used for each plate. The plates were then taken in an incubator at $37^{\circ} \mathrm{c}$ for $24-48$ hours. Following incubation, plates exhibiting 30-300 colonies were counted. The average number of colonies in a particular dilution was multiplied by the dilution factor to obtain the total Coliform count. The total Coliform count was calculated according to ISO (1995). The result of total bacterial count was expressed as the number of organism or colony forming units per milliliter (CFU/ $\mathrm{ml}$ ) of water samples.

Data analysis

For data processing, Microsoft Excel spreadsheet (2007) and SPSS16 were used.

\section{Results}

\section{Qualitative assessment}

The qualitative assessment of bottled water is evaluated by responder's perception using the questionnaire provided in the section of Materials and Methods. The distribution of the study subject as per demographic and bottled water consumption is summarized in Table 1 . Among the respondents, the maximum $(60 \%)$ belong to the age group of $12-24$ years, where the lowest $(13.3 \%)$ presenting the age groups of $37+$ years. In terms of educational qualification, the highest numbers $(66.7 \%)$ were undergraduate respondents, followed by Higher Secondary School Certificate (H.S.C.) examination candidates $(10 \%)$. During the study period it was observed that, for the most part $(60 \%)$ of the respondents were living in Mymensingh city for 0 to 10 years, followed by $11-20$ years $(30 \%)$ and $21+$ years $(10 \%)$. It was observed that, out of 30 respondents, the highest $(90 \%)$ number of respondent was overwhelming bottled water in diverse situations for different purpose. A total of $70 \%$ respondents said that they had been consuming bottled water for longer period of time because of health consciousness. Scarcity of treated drinking water is another important reason of consumption of bottled water (estimated around 13.3\%). The other reasons include the easy access to the bottled water from various sources and the ease of portability, as opined by the responded $10 \%$ and $6.7 \%$, respectively. Around $50 \%$ of the total respondents were consuming bottled water for 6-10 years and $43.3 \%$ of the respondents were found to consume bottled water for a period of $11+$ years. About $6.7 \%$ respondents were also found to consume bottled water for a period of 0-5 years. In the present study, it was observed that the respondents were distinguishing good or bad bottled water on the basis of some criteria. The highest number of respondents (43.3\%) prioritized taste while choosing good quality bottled water. About $20 \%$ and $16.7 \%$ of the respondent also viewed that, clarity and minera composition of the water respectively, should also be considered as deterministic criteria to be good quality bottled water.
Bangladesh Standards and Testing Institution (BSTI) approval ranked third $(10 \%)$, as the criteria for selecting good quality bottled water. Only a few, $6.7 \%$ and $3 \%$, rely on outlook and popularity as a deterministic criterion to be good quality bottled water, respectively.

The responders' satisfactions, perceptions and expenditures on bottled water quality are summarized in Table 2 . A total of $40 \%$ of the respondents considered that the quality of bottled water has been satisfactory, on the contrary to the $30 \%$ of the respondents, who judged that, the quality of bottled water was not that satisfactory. However, the $20 \%$ of the respondents didn't know whether the quality of the bottled water was good or bad.

During the study period, respondents were asked whether they consumed bottled water instead of municipal water, if the quality were highly maintained. Highest $(50 \%)$ number of respondents positively reacted, while $20 \%$ of the respondents replied that, they would not do so. A good number $(30 \%)$ of respondents were in doubt. During the study period, $46.7 \%$ respondents expressed that the price of bottled water was satisfactory in comparison with the quality they were getting. However, $40 \%$ thought that the price of bottled water was not so satisfactory. It was observed that, $80 \%$ respondents' monthly expenditures on bottled water was less than 300 taka. A total of $13.3 \%$ respondents were found whose monthly expenditure for buying bottled water was more than 500 taka. During the study period, respondents were asked about the consequence of the empty bottled water after consumption. A total of $26.7 \%$ respondents alleged that they throw the bottles anywhere after consuming the water from the bottles. A total of $40 \%$ respondents replied that they dumped the bottles in dustbins, and $33.3 \%$ said they reused those bottles. Again when the respondents were asked whether the dumping of empty water bottles to open spaces or roadsides could be hazardous for environment, $80 \%$ respondents considered that the empty bottles could be environmentally hazardous due to their non biodegradable plastic content as well as for clogging of drainage system. $3.3 \%$ respondents thought it was not so environmentally hazardous compared to $6.7 \%$ respondents who never thought about such problem. Respondents were also asked whether the contaminated bottled waters were adverse for health or not. A total of $70 \%$ of the total respondents had the realization that the contaminated bottled water would adversely affect human health, whereas about $10 \%$ considered it would not affect the human health, and the $20 \%$ had no idea on this issue. A total of $76.7 \%$ respondents told that they consumed bottled water only when they were outside the home, whereas about $10 \%$ respondents were found to consume bottled water every day, while a good number $(13.3 \%)$ of respondents only consumed bottled water in fast food stores and restaurants.

\section{Bacteriological assessment}

Heterotrophic plate count (geometric mean) of bottled water was presented in Table 3. The geometric mean of HPC of brand A, brand $\mathrm{B}$, brand $\mathrm{C}$, brand $\mathrm{D}$, brand $\mathrm{E}$ and brand $\mathrm{F}$ bottled water were $3.7 \times 10^{3}, 4.1 \times 10^{3}, 6.2 \times 10^{3}, 4.0 \times 10^{3}, 2.9 \times 10^{3}$ and $5.2 \times 10^{3}$ $\mathrm{cfu} / 100 \mathrm{ml}$, respectively. However, the total geometric mean of HPC of different brands of bottled water was $4.3 \times 10^{3} \mathrm{cfu} / 100$ $\mathrm{ml}$

The summary of total coliform count in bottled water is presented in Table 4. The geometric mean of TCC of brand A, brand $\mathrm{B}$, brand $\mathrm{C}$, brand $\mathrm{D}$, brand $\mathrm{E}$ and brand $\mathrm{F}$ bottled water were $18,12,26,12,9,43 \mathrm{cfu} / 100 \mathrm{ml}$ respectively.

\section{Discussion}

The objective of this research work was to assess the overall quality of bottled water (both qualitative and bacteriological) available in Mymensingh city of Bangladesh. Qualitative assessment of bottled water indicated that a good number of 
Table1. Demographic attributes towards bottled water consumption

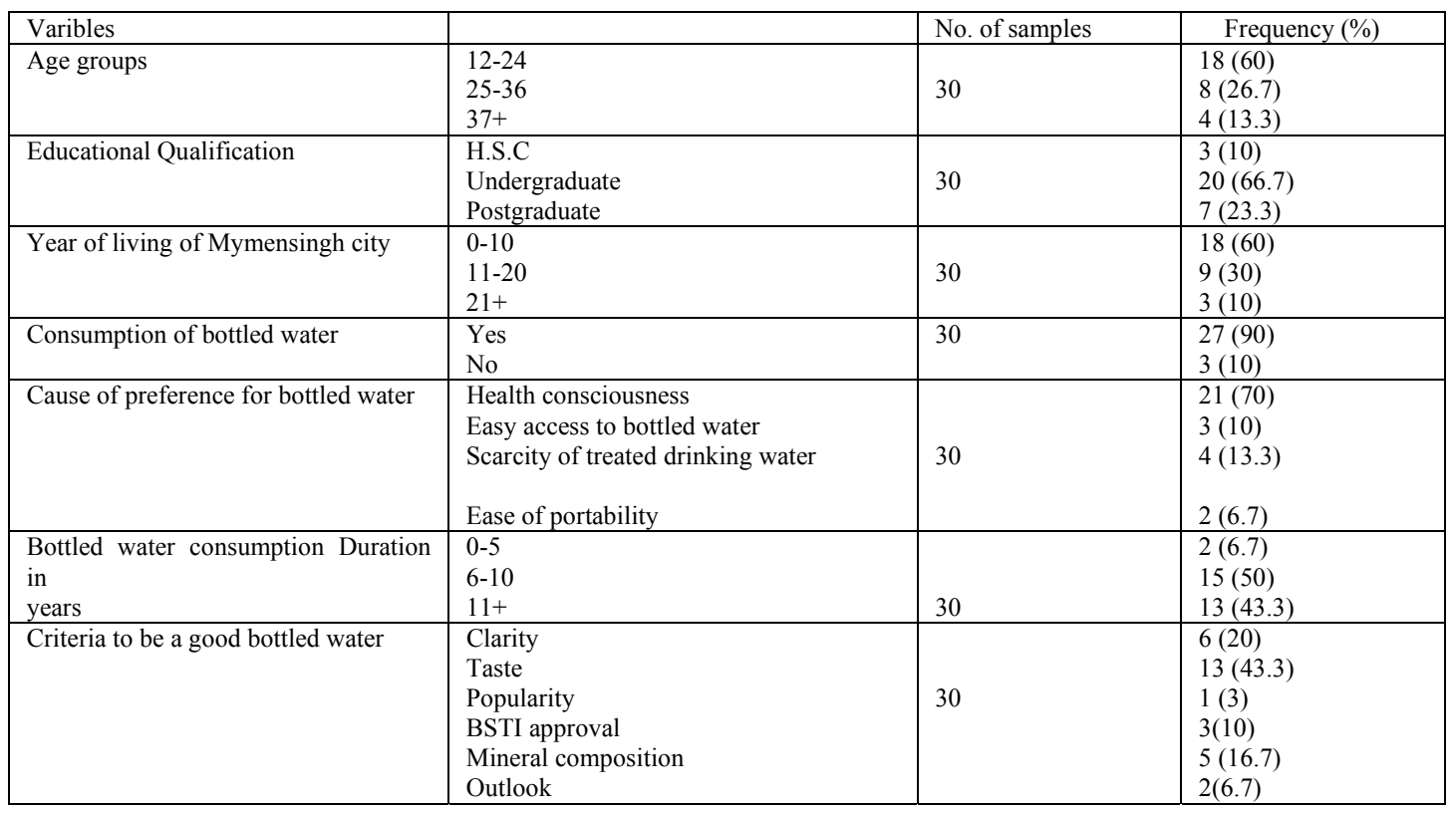

Table 2. Consumers perceptions towards bottled water quality

\begin{tabular}{|c|c|c|c|}
\hline Variables & & No. of samples & Frequency $(\%)$ \\
\hline Perception & $\begin{array}{l}\text { Satisfactory } \\
\text { Not satisfactory } \\
\text { Not known } \\
\text { Never thought about }\end{array}$ & 30 & $\begin{array}{l}12(40) \\
9(30) \\
6(20) \\
3(10)\end{array}$ \\
\hline Substitute of municipal water & $\begin{array}{l}\text { It Yes } \\
\text { No } \\
\text { Not known } \\
\end{array}$ & 30 & $\begin{array}{l}15(50) \\
6(20) \\
9(30) \\
\end{array}$ \\
\hline Post consumption dumping place & $\begin{array}{l}\text { Throw Anywhere } \\
\text { Throw to Dustbin } \\
\text { Refuse it }\end{array}$ & 30 & $\begin{array}{l}8(26.7) \\
12(40) \\
10(33.3)\end{array}$ \\
\hline Effect of contamination & $\begin{array}{l}\text { Adverse } \\
\text { Not so adverse } \\
\text { Not known }\end{array}$ & 30 & $\begin{array}{l}21(70) \\
3(10) \\
6(20)\end{array}$ \\
\hline Effect of indiscriminate dumping & $\begin{array}{l}\text { Hazardous } \\
\text { Not so hazardous } \\
\text { Not known } \\
\text { Never thought of it }\end{array}$ & 30 & $\begin{array}{l}24(80) \\
1(3.3) \\
3(10) \\
2(6.7)\end{array}$ \\
\hline Frequency of consumption of bottled water & $\begin{array}{l}\text { Everyday } \\
\text { Only outside } \\
\text { Fast food shop }\end{array}$ & 30 & $\begin{array}{l}3(10) \\
23(76.7) \\
4(13.3)\end{array}$ \\
\hline
\end{tabular}


Table 3. Determination of heterotrophic plate count in bottled water

\begin{tabular}{|c|c|c|c|c|}
\hline $\begin{array}{l}\text { Brand of } \\
\text { bottled water }\end{array}$ & Sample code & $\begin{array}{l}\text { HPC } \\
(\mathrm{cfu} / 100 \mathrm{ml})\end{array}$ & $\begin{array}{l}\text { Geometric mean of HPC } \\
(\mathrm{cfu} / 100 \mathrm{ml})\end{array}$ & $\begin{array}{l}\text { Total Geometric mean of } \\
\text { HPC } \\
(\mathrm{cfu} / 100 \mathrm{ml})\end{array}$ \\
\hline \multirow{3}{*}{ A } & $\mathrm{MW}_{\mathrm{a}} 1$ & $3.5 \times 10^{3}$ & \multirow{3}{*}{$3.7 \times 10^{3}$} & \multirow{18}{*}{$4.3 \times 10^{3}$} \\
\hline & $\mathrm{MW}_{\mathrm{a}} 2$ & $4.0 \times 10^{3}$ & & \\
\hline & $\mathrm{MW}_{\mathrm{a}} 3$ & $3.6 \times 10^{3}$ & & \\
\hline \multirow{3}{*}{ B } & $\mathrm{MW}_{\mathrm{b}} 1$ & $4.5 \times 10^{3}$ & \multirow{3}{*}{$4.1 \times 10^{3}$} & \\
\hline & $\mathrm{MW}_{\mathrm{b}} 2$ & $4.3 \times 10^{3}$ & & \\
\hline & $\mathrm{MW}_{\mathrm{b}} 3$ & $3.6 \times 10^{3}$ & & \\
\hline \multirow{3}{*}{$\mathrm{C}$} & $\mathrm{MW}_{\mathrm{c}} 1$ & $6.3 \times 10^{3}$ & \multirow{3}{*}{$6.2 \times 10^{3}$} & \\
\hline & $\mathrm{MW}_{\mathrm{c} 2} 2$ & $5.8 \times 10^{3}$ & & \\
\hline & $\mathrm{MW}_{\mathrm{c}} 3$ & $6.7 \times 10^{3}$ & & \\
\hline \multirow{3}{*}{$\mathrm{D}$} & $\mathrm{MW}_{\mathrm{d}} 1$ & $3.2 \times 10^{3}$ & \multirow{3}{*}{$4.0 \times 10^{3}$} & \\
\hline & $\mathrm{MW}_{\mathrm{d}} 2$ & $3.5 \times 10^{3}$ & & \\
\hline & $\mathrm{MW}_{\mathrm{d}} 3$ & $5.3 \times 10^{3}$ & & \\
\hline \multirow{3}{*}{ E } & $\mathrm{MW}_{\mathrm{e}} 1$ & $2.7 \times 10^{3}$ & \multirow{3}{*}{$2.9 \times 10^{3}$} & \\
\hline & $\mathrm{MW}_{\mathrm{e}} 2$ & $3.7 \times 10^{3}$ & & \\
\hline & $\mathrm{MW}_{\mathrm{e}} 3$ & $2.4 \times 10^{3}$ & & \\
\hline \multirow{3}{*}{$\mathrm{F}$} & $\mathrm{MW}_{\mathrm{f}} 1$ & $5.4 \times 10^{3}$ & \multirow{3}{*}{$5.2 \times 10^{3}$} & \\
\hline & $\mathrm{MW}_{\mathrm{f}} 2$ & $5.8 \times 10^{3}$ & & \\
\hline & $\mathrm{MW}_{\mathrm{f}} 3$ & $4.6 \times 10^{3}$ & & \\
\hline
\end{tabular}

$\mathrm{HPC}=$ Heterotrophic Plate Count.

Table 4. Determination of total coliform count in bottled water

\begin{tabular}{|c|c|c|c|}
\hline $\begin{array}{l}\text { Brand of } \\
\text { bottled water }\end{array}$ & Sample code & $\begin{array}{l}\text { TCC } \\
(\mathrm{cfu} / 100 \mathrm{ml})\end{array}$ & $\begin{array}{l}\text { Geometric mean of TCC } \\
(\mathrm{cfu} / 100 \mathrm{ml})\end{array}$ \\
\hline \multirow{3}{*}{ A } & $\mathrm{MW}_{\mathrm{a}} 1$ & 12 & \multirow{3}{*}{18} \\
\hline & $\mathrm{MW}_{\mathrm{a}} 2$ & 19 & \\
\hline & $\mathrm{MW}_{\mathrm{a}} 3$ & 22 & \\
\hline \multirow{3}{*}{ B } & $\mathrm{MW}_{\mathrm{b}} 1$ & 7 & \multirow{3}{*}{12} \\
\hline & $\mathrm{MW}_{\mathrm{b}} 2$ & 13 & \\
\hline & $\mathrm{MW}_{\mathrm{b}} 3$ & 17 & \\
\hline \multirow{3}{*}{$\mathrm{C}$} & $\mathrm{MW}_{\mathrm{c}} 1$ & 23 & \multirow{3}{*}{26} \\
\hline & $\mathrm{MW}_{\mathrm{c}} 2$ & 27 & \\
\hline & $\mathrm{MW}_{\mathrm{c}} 3$ & 29 & \\
\hline \multirow{3}{*}{ D } & $\mathrm{MW}_{\mathrm{d}} 1$ & 15 & \multirow{3}{*}{12} \\
\hline & $\mathrm{MW}_{\mathrm{d}} 2$ & 9 & \\
\hline & $\mathrm{MW}_{\mathrm{d}} 3$ & 11 & \\
\hline \multirow{3}{*}{$\mathrm{E}$} & $\mathrm{MW}_{\mathrm{e}} 1$ & 6 & \multirow{3}{*}{9} \\
\hline & $\mathrm{MW}_{\mathrm{e}} 2$ & 9 & \\
\hline & $\mathrm{MW}_{\mathrm{e}} 3$ & 13 & \\
\hline \multirow{3}{*}{$\mathrm{F}$} & $\mathrm{MW}_{\mathrm{f}} 1$ & 39 & \multirow{3}{*}{43} \\
\hline & $\mathrm{MW}_{\mathrm{f}} 2$ & 43 & \\
\hline & $\mathrm{MW}_{\mathrm{f}} 3$ & 48 & \\
\hline
\end{tabular}

TCC $=$ Total Coliform Count. 
people preferred bottled water rather than tap water in this study. The age group belonging to $12-24$ years preferred bottled water mostly $(60 \%)$. However, $66.7 \%$ undergraduate student preferred bottled water for their daily consumption. In this study, the cause of preference of bottled water was health consciousness, which is $70 \%$ of the total peoples. The criteria to be a good bottled water was taste $(43.3 \%)$. The bottled water quality was satisfactory in $40 \%$ of the peoples in this study on the basis of people's satisfaction, perception and expenditure on bottled water quality. On the other hand, the percentage of dumping of bottled water after consumption refuse was $33.3 \%$. Moreover, monthly expenditure on bottled water was less than 300 taka in $80 \%$ of the total people. The findings of the present study are more or less similar to the findings of Majumder et al. (2011).

Heterotrophic plate count and total coliform count are commonly used to assess the general microbiological quality of bottled water. The HPC of bottled water of different brands such as $\mathrm{A}, \mathrm{B}, \mathrm{C}, \mathrm{D}, \mathrm{E}$, and $\mathrm{F}$ were $3.7 \times 10^{3}, 4.1 \times 10^{3}, 6.2 \times 10^{3}, 4.0 \times 10^{3}$, $2.9 \times 10^{3}$ and $5.2 \times 10^{3} \mathrm{cfu} / 100 \mathrm{ml}$ respectively in this study. HPC was found lowest in brand $\mathrm{E}$ bottled water but highest in brand $\mathrm{C}$ bottled water in this study. However, the total geometric mean of HPC of different brands of bottled water was $4.3 \times 10^{3} \mathrm{cfu} / 100$ $\mathrm{ml}$ in this study. According to the world health report (2002), drinking water quality specifications world-wide recommend HPC limits $50 \mathrm{cfu} / \mathrm{ml}$ in bottled water. In case of HPC, the findings of the present study differ with the findings of Islam et al. (2010) who found the geometric mean of mineral water was $1.0 \times 10^{2} \mathrm{cfu} / 100 \mathrm{ml}$. On the other hand, Zam et al. (2010) found the values of HPC between less than 10 and $72,000 \mathrm{cfu} / \mathrm{ml}$ for ten different brands of bottled water. Furthermore, the geometric mean of TCC of different brands such as A, B, C, D, E, and F were $18,12,26,12,9,43 \mathrm{cfu} / 100 \mathrm{ml}$ respectively. TCC was found lowest in brand $\mathrm{E}$ bottled water but highest in brand $\mathrm{F}$ bottled water in this study. In this study, brand E bottled water was found to be best in terms of microbiological quality when compared with other brands of bottled water available in Mymensingh city of Bangladesh. However, not a single brand was found totally free from coliform. The presence of total and fecal coliform in bottled water samples has been reported to be due to poor hygienic practices of the producers, failure to wash hands, illiteracy and unhygienic practices of vendors (Coroler $e$ al., 1996).

\section{Conclusion}

The bottled water market has steadily increased over the last decade and is now the largest category of commercial beverage sold by volume in Bangladesh. Many prefer bottled water over tap water for a number of reasons. People may not like the taste, smell or color of bottled water, but they continue to drink bottled water despite quality concerns. On the other hand, some people are worried about their health and perceive bottled water as more natural, pure and a healthier alternative to supplied water by local authorities. Therefore, ever-increasing demand for bottled water is continuing in Bangladesh. Quality differences among different brands of bottled water were observed. Analysis of 30 bottled water samples showed a wide assortment of microbial qualities. Generally, bottled water is good for drinking in Bangladesh. However, bottled water quality in Bangladesh needs to be monitored regularly. Indeed, it is a requirement that a tri-monthly monitoring should be carried out on water quality of bottled water of different brands, generally by BSTI and by the Ministry of Health in Bangladesh.

\section{Acknowledgement}

The authors thank his scientific colleagues for valuable comments on the manuscript. This study was performed in partial fulfillment of the requirements of a M.S. thesis for Shabnam Sharmin from the Department of Microbiology and Hygiene, Bangladesh Agricultural University, Mymensingh, Bangladesh. Shabnam Sharmin was a recipient of NST fellowship from the Ministry of Science and Technology, Government of the People's Republic of Bangladesh.

\section{References}

American Academy of Microbiology,1996. A Global Decline in Microbiological Safety of Water: A Call for Action. American Society of Microbiology, Washington.

Coroler L, M Elomari, B Hoste, M Gillis, D Izard and $\mathrm{H}$ Leclerc,1996. Pseudomonas rhodesiae sp. nov., a new species isolated from natural mineral waters. Syst Appl Microbiol, 19: 600-607.

Islam S, HA Begum and NY Nili, 2010. Bacteriological safety assessment of municipal tap water and quality of bottle water in Dhaka City: health hazard analysis. Bangladesh. J Med Microbiol, 4: 9-13.

ISO, 1995. Recommendation of the meeting of the subcommittee, International Organization for Standardization, on meat and meat products. ISO/TC-36/Sc-6.The Netherlands. 10-18.

Johnson, JYM, JE Thomas, TA Graham, I Townshend, J Byrne, LB Selinger and VPJ Gannon, 2003. Prevalence of Escherichia coli 0157:H7 Salmonella spp. in surface waters of southern Alberta and its relation to manure sources. Canadian J Microbiol, 49: 326-335.

Liguori G, I Cavallotti, A Arnese, C Amiranda, D Anastasi and IF Angelillo, 2010. Microbiological quality of drinking water from dispensers in Italy. BMC Microbiol, 10:19-24.

Loy A, W Beisker and H Meier, 2005. Diversity of bacteria growing in natural mineral water after bottling. Appl Environ Microbiol, 71:3624-3632.

Majumder AK, NKM Islam, RN Nite and R Noor, 2011. Evaluation of microbiological quality of commercially available bottled water in the city of Dhaka, Bangladesh. S J Microbiol, 1: 24-30.

Moe CL, MD Sobsey, GP Samsa and V Mesolo, 1991. Bacterial indicators of risk of diarrhoeal disease from drinking water in the Philippines. Bull World Health Organ, 69: 305-317.

The World Health Report, 2002. Geneva: World Health Organization, 2001

Venter SN, 2000. Rapid Microbiological Monitoring Methods: the Status Quo. International Water Associations Blue Pages.

Zam AS, M Marino and A Khameesan, 2010. A random study of the microbiological quality of bottled drinking water in Canada. Proceeding of the 110 th American Society for Microbiology (ASM) Conference, Paper No. 4016 